\title{
PENGEMBANGAN BRIKET JERAMI PADI (ORYZA SATIVA) YANG MENGANDUNG ISOLAT BAKTERI PENDEGRADASI MINYAK BUMI SEBAGAI UPAYA MENGATASI PENCEMARAN DI PERAIRAN LAUT
}

\author{
Ni Putu Ristiati, Sanusi Mulyadiharja \\ Jurusan Pendidikan Biologi, Fakultas Matematika IImu Pengetahuan Alam \\ Undiksha Singaraja \\ e-mail: puturistiati@gmail.com
}

\begin{abstract}
Abstrak
Penelitian ini bertujuan untuk mengetahui: (1) komposisi briket jerami yang paling baik untuk pertumbuhan isolat bakteri pendegradasi solar, (2) karakteristik isolat bakteri dari ke lima genus bakteri pendegradasi solar yang paling baik tumbuh dalam briket jerami, (3) isolat bakteri pendegradasi minyak solar mampu mendegradasi secara soliter atau dalam bentuk konsorsium. Penelitian ini tergolong penelitian eksperimental. Pengumpulan data dalam penelitian ini dilakukan dengan dua cara (1) pengambilan data di lapangan, (2) analisis sampel di laboratorium. Hasil penelitian menunjukkan bahwa (1) komposisi 4\% merupakan komposisi yang optimum untuk pertumbuhan bakteri pendegradasi solar,(2) didapatkan 4 genus bakteri yang mampu tumbuh pada media yang telah diberikan jerami padi. Genus tersebut antara lain Pseudomonas, Acetobacter, Neisseria , dan Halomonas. Jumlah total koloni paling rendah terdapat pada genus Halomonas, kemudian semakin bertambah pada genus Acetobacter, Neisseria, dan jumlah total koloni paling tinggi ada pada Pseudomonas, (3) Isolat bakteri pendegradasi minyak solar mampu mendegradasi secara soliter atau dalam bentuk konsorsium tetapi dalam bentuk konsorsium pertumbuhan lebih optimum.
\end{abstract}

Kata kunci: Jerami padi, isolat bakteri, briket

\begin{abstract}
Purpose of this research to know : (1) the best composition of straw briquet for growth bacteria isolate degradation diesel-fuel, (2) Bacteria isolate characteristic from the fifth genus degradation solar to grow best in straw briquet, (3) diesel-fuel degradation isolate bacteria can degradation solitaire or consorsium. This research include in experimental research. Data collected in two ways (1) data from field research, (2) sample analysis in laboratory. Results of this research (1) $4 \%$ composition its optimum composition for growth degradation diesel-fuel bacteria, (2) 4 genus bacteria can grow in media its fill in with straw briquette. That genus i.e Pseudomonas, Acetobacter, Neisseria, and Halomonas. The lowest sum total colony in Halomonas, more added in Acetobacter, Neisseria, the highest sum total colony in Pseudomonas, (3) Bacteria isolate degradation diesel-fuel can degradation solitaire or consorsium but in consorsium the growth more optimum.
\end{abstract}

Key words : straw, bacteria isolate, briquet 


\section{PENDAHULUAN}

Sumber pencemaran yang paling tinggi dewasa ini adalah dari tumpahan minyak bumi. Minyak bumi digunakan sebagai sumber energiutama keperluan dunia dan bahan baku industri petrokimia, diangkut secara besarbesaran ke seluruh penjuru dunia dengan kapal tanker. Dampak pencemaran barang beracun dan berbahaya terutama minyak karena minyak merupakan pencemar terbesar dewasa ini terhadap lingkungan maritim. Apabila minyak tumpah ke laut berdasarkan hasil penyelidikan IMO (International Maritime Organization) selama ini akan menyebabkan kerugian di bidang ekologi, tempat rekreasi, lingkungan pelabuhan dan dermaga, instalasi industri, perikanan, hewan, tumbuhan, terumbu karang, dan taman laut (Pieter Batti, 2000).

Secara umum penanggulangan limbah minyak dapat dilakukan secara fisik, kimia, dan biologi. Secara fisik umumnya dilakukan pada langkah awal penanganan. Tumpahan minyak bumi diisolir secara cepat sebelum minyak tersebut menyebar kemana-mana. Minyak bumi yang terkumpul di permukaan dapat diambil kembali misalnya dengan oil skimmer, sedangkan yang mengendap sulit diambil secara fisika (Hommel \& Ratledge, 2007)

Secara kimia, metode yang biasa dipakai adalah menggunakan dispersan, yaitu zat kimia yang dirancang untuk disemprotkan ke atas lapisan minyak, untuk mempercepat proses dispersi alami. Mengatasi tumpahan minyak dengan cara menyemprotkan dispersan ini tidak efektif untuk diterapkan pada kasus-kasus kecil, karena disamping volume limbahnya sedikit dan tempatnya tersebar sehingga sulit untuk diolah, bahkan dispersan mempunyai sifat racun yang lebih besar dari minyak itu sendiri (Setiana, 1991). Reisfeld et al. (1972) mengemukakan tentang penggunaan mikroba untuk membantu meningkatkan biodegradasi minyak bumi sehingga dapat mengurangi pencemaran. Secara biologis, biodegradasi oleh mikroba merupakan salah satu cara yang tepat, efektif dan hampir tidak ada pengaruh sampingan pada lingkungan karena tidak menghasilkan racun ataupun blooming karena mikroba ini akan mati seiring dengan habisnya minyak. Aktivitas organisme mampu membantu proses pembersihan tumpahan minyak dengan mengoksidasi minyak menjadi $\mathrm{CO}_{2}$ dan $\mathrm{H}_{2} \mathrm{O}$. Dalam lingkungan laut, aktivitas degradasi hidrokarbon oleh mikroba dibatasi minimnya konsentrasi nutrisi yaitu nitrogen dan fosfor. Penambahan nitrogen dan fosfor ke dalam komponen minyak dapat merangsang proses biodegradasi tumpahan minyak (Iwabuchi et al.,2002).

Proses dekomposisi minyak dan produk minyak di alam secara ekonomis sangat penting. Minyak banyak mengandung bahan organik, hidrokarbonnya banyak dimanfaatkan oleh mikroba dalam proses kehidupannya. Proses oksidasi hidrokarbon oleh bakteri dan fungi banyak membantu proses dekomposisi minyak dan produk minyak. Oksidasi hidrokarbon oleh mikroba tergantung pada faktor lingkungan seperti suhu, $\mathrm{pH}$, dan nutrisi (Rebecca et al, 2002). 
Pelabuhan Celukan Bawang yang terletak di Gerokgak, 50 kilometer barat Singaraja menjadi pusat bongkar muat angkutan barang dari pulau lain. Berdasarkan uraian di atas, maka perlu dilalukan pengembangan teknologi mikroba pendegradasi minyak bumi sebagai plasma nuftah dari perairan tropis.

Berdasarkan latar belakang masalah yang telah diuraikan, maka tujuan penelitian ini adalah untuk mengetahui : (1) komposisi briket jerami yang paling baik untuk pertumbuhan isolat bakteri pendegradasi solar, (2) karakteristik isolat bakteri dari ke lima genus bakteri pendegradasi solar yang paling baik tumbuh dalam briket jerami, (3) isolat bakteri pendegradasi minyak solar mampu mendegradasi secara soliter atau dalam bentuk konsorsium.

\section{METODE PENELITIAN Rancangan Penelitian}

Rancangan dalam penelitian ini merupakan eksperimen sungguhan (True experimental). Rancangan penelitian eksperimen yang digunakan adalah : The Randomized Posttest-
Only Control Group Design (Zaenuddin, 1994; Bawa, 2000).

Populasi dalam penelitian perairan pelabuhan Celukan Bawang, Singaraja. Sampel dalam penelitian ini adalah air laut yang mengandung minyak solar. Jumlah ulangan 9 kali berdasarkan ( $\mathrm{T}$ 1)(R-1) $\geq 15$ (Rochiman, 1989) dimana $\mathrm{T}=$ perlakuan dan $\mathrm{R}=$ replikasi. Unit percobaan berjumlah 9 cawan petri berisi medium untuk menumbuhkan mikroba. Jumlah seluruh unit percobaan menjadi 27 unit.

Analisis data diuji dengan ANAVA (analisis varians) satu arah, dilanjutkan dengan uji perbandingan ganda (multiple comparison : Post Hock) antar kelompok untuk menguji beda rerata kelompok kontrol dan kelompok eksperimen.

\section{HASIL DAN PEMBAHASAN}

Berdasarkan hasil penelitian, jumlah total koloni bakteri yang paling rendah pada komposisi $8 \%$, kemudian semakin meningkat pada komposisi kontrol, 1\%, dan yang paling tinggi pada komposisi $4 \%$. Jumlah total rata-rata koloni bakteri yang tumbuh dapat digambarkan dengan diagram batang pada gambar 1

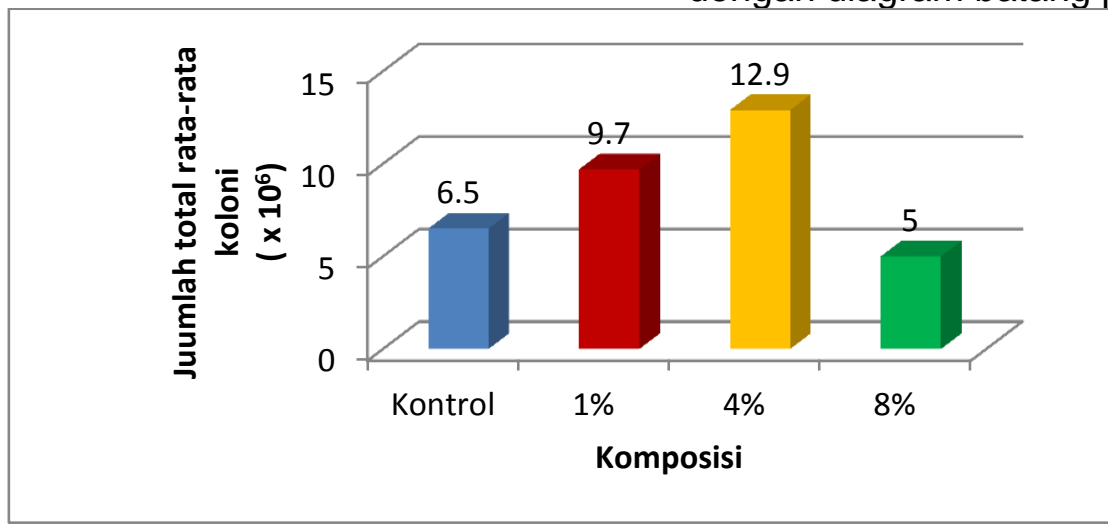

Gambar 1. Diagram Batang Jumlah Total Rata-Rata Koloni Bakteri Pendegradasi Solar dengan Pemberian Jerami Padi per Mililiter 
Pada pembiakan bakteri yang diambil dari isolat polikultur bakteri pendegradasi solar, terdapat tujuh jenis isolat bakteri berbeda yang dapat tumbuh pada media Bushnell-Haas Mineral Salts cair berisi jerami dengan komposisi $4 \%$. Tujuh jenis isolat bakteri tersebut terdiri atas bakteri yang diberi label A, B, C, D, E, F, dan G. Berdasarkan karakteristikkarakteristiknya, isolat tersebut dapat dikelompokkan ke dalam empat genus bakteri yaitu : (1) Pseudomonas (isolat
A, F, dan G), (2) Acetobacter (isolat B), (3) Neisseria (isolat C dan D), dan (4) Halomonas (isolat E).

Berdasarkan penelitian, dapat diketahui bahwa jumlah total pertumbuhan koloni tertinggi terdapat pada genus bakteri Pseudomonas (isolat $A, F$, dan $G$ ). Jumlah total ratarata koloni bakteri untuk masing-masing genus yang tumbuh dari penelitian ini dapat digambarkan dengan diagram batang pada gambar 2 .

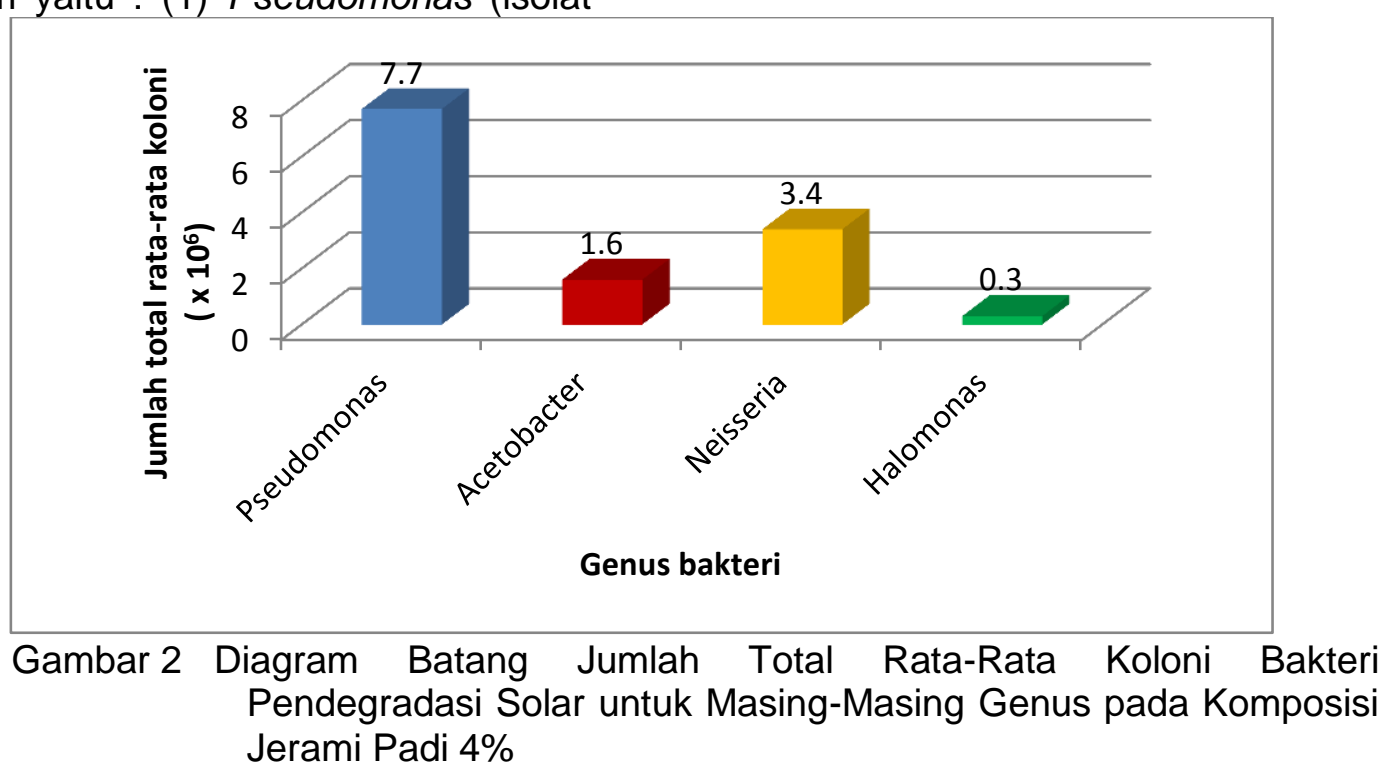

Data dari polikultur bakteri yang ada di laboratorium pada media BushnellHaas Mineral Salt yang diberi jerami padi adalah berupa karakteristik koloni bakteri, karakteristik sel isolat bakteri, dan hasil uji biokimia pada isolat bakteri. 
A

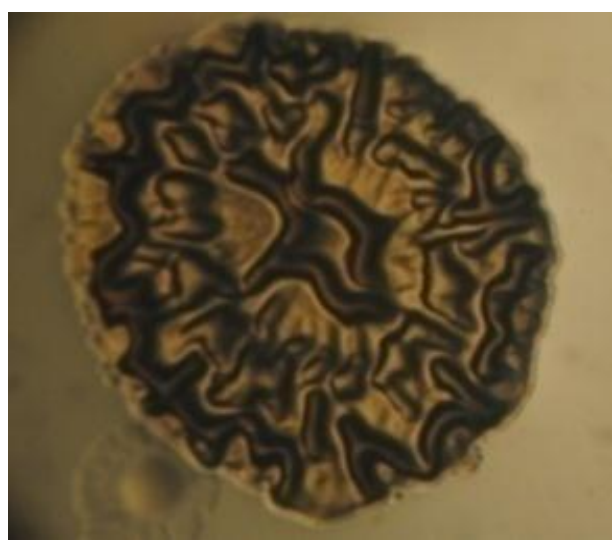

C

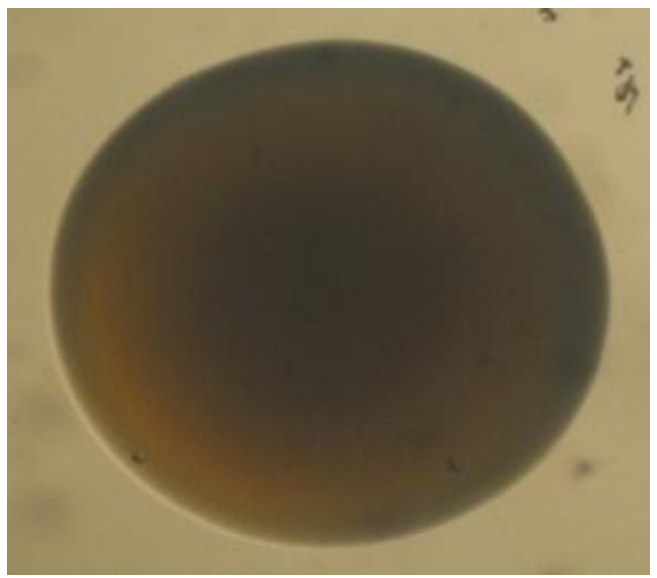

E

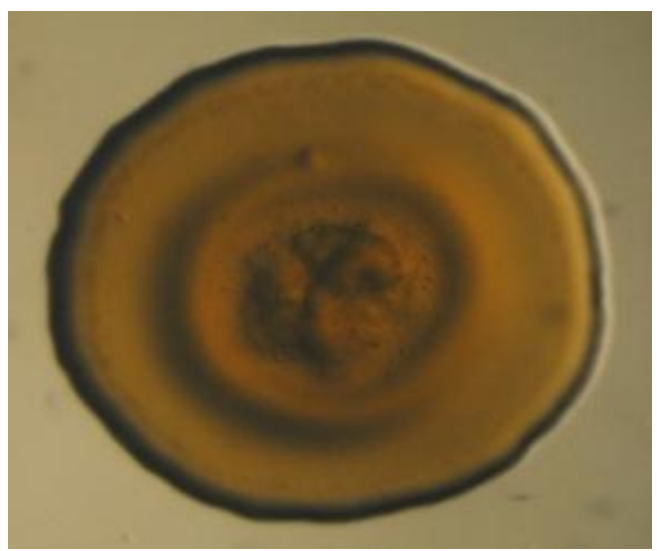

B

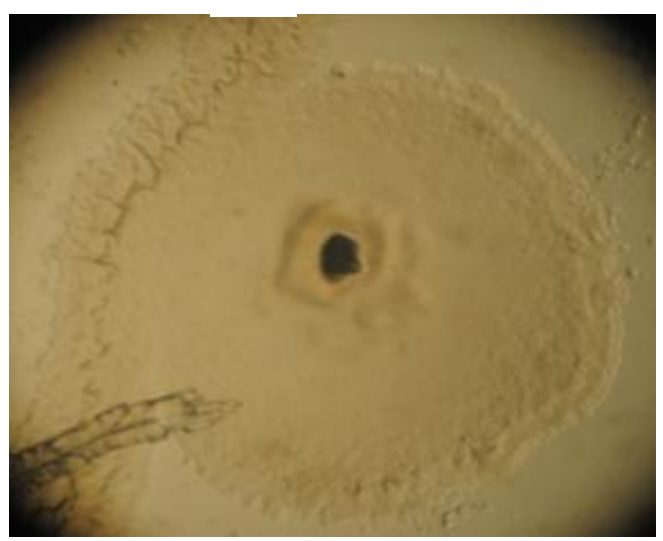

D

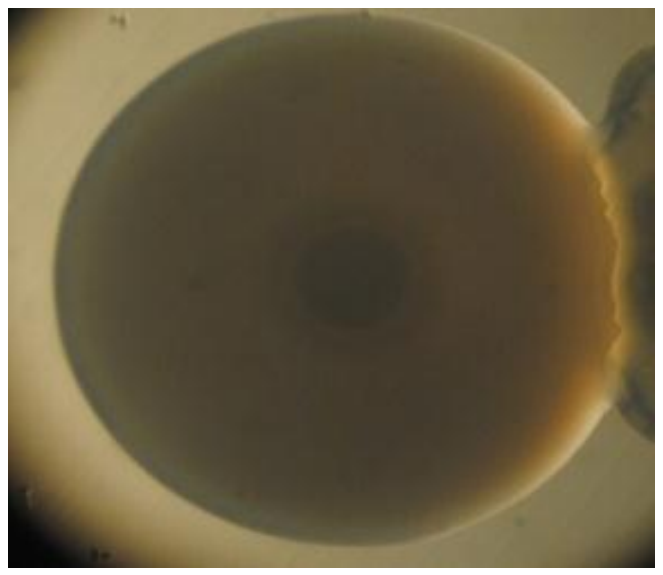

F 
G

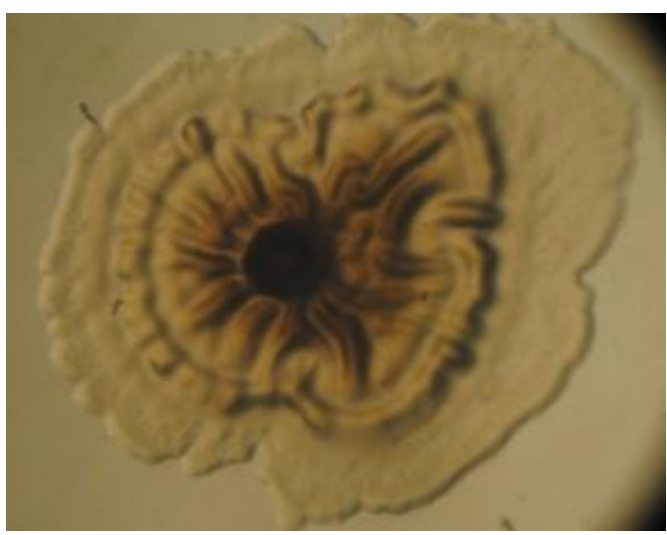

\section{PEMBAHASAN}

Berdasarkan hasil penelitian, diperoleh data terjadi peningkatan jumlah total koloni mulai dari komposisi kontrol $0 \%$ ke komposisi $1 \%$, semakin meningkat dan optimum pada komposisi $4 \%$. Namun, pada komposisi $8 \%$ total koloni menurun drastis. Hal ini membuktikan bahwa pemberian jerami berpengaruh terhadap pertumbuhan bakteri yang ditunjukkan dengan perbedaan jumlah total koloni yang tumbuh pada media. Pengaruh yang timbul tersebut disebabkan karena jerami padi merupakan substrat yang mengandung unsur nutrisi pertumbuhan bagi mikroba khususnya bakteri pendegradasi hidrokarbon. Menurut Gunam, dkk. (2010) bahwa pembuatan enzim selulase dari limbah jerami padi sebagai substrat dengan menggunakan mikroorganisme sebagai penghasil enzim, selain mudah dibiakan, mikroorganisme juga mempunyai kecepatan tumbuh yang tinggi dan mudah dikontrol pertumbuhannya. Bakteri dalam aktivitas hidupnya memerlukan molekul karbon sebagai salah satu sumber nutrisi dan energi
Gambar 3 Karakteristik Koloni Isolat Bakteri yang Mampu Tumbuh pada Pemberian Jerami dengan Komposisi Keterangan 4\% (Perbesaran 1000x)

A: isolat Pseudomonas, $B$ : isolat Acetobacter, C: isolat Neisseria, $D$ : isolat Neisseria, E:isolat Halomonas,F:isolat Pseudomonas, G:isolat Pseudomonas.

untuk melakukan metabolisme dan perkembangbiakannya. Fraksi hidrokarbon yang digunakan oleh bakteri sebagai sumber karbon dan energi dapat berasal dari fraksi hasil pemecahan hidrokarbon oleh dirinya sendiri maupun fraksi hasil pemecahan hidrokarbon oleh jenis lainnya.

Karbon yang tersedia pada hidrokarbon minyak bumi dimanfaatkan oleh bakteri sebagai sumber energi bagi pertumbuhan dan perkembangan selnya serta aktivitas enzim yang dihasilkan oleh bakteri untuk mendegradasi polutan. Selain karbon, untuk pertumbuhannya bakteri juga memerlukan unsur lain yaitu, nitrogen, fosfor, belerang, kalium, magnesium dan besi. Dari deretan unsur tersebut, nitrogen dan fosfor merupakan unsur esensial untuk mendukung biodegradasi hidrokarbon minyak bumi. Unsur $\mathrm{N}$ dibutuhkan untuk biosintesis asam amino yang merupakan monomer protein, sedangkan $P$ dibutuhkan untuk biosintesis DNA dan RNA serta transfer energi. Protein selain sebagai pembentuk enzim, juga merupakan penyusun struktur sel sehingga 
komposisinya dalam sel lebih besar dibandingkan dengan unsur $P$. Rasio $\mathrm{C} / \mathrm{N}$ yang rendah (kandungan unsur $\mathrm{N}$ yang tinggi) akan meningkatkan emisi dari nitrogen sebagai amonium yang dapat menghalangi perkembangbiakan bakteri. Sedangkan rasio $\mathrm{C} / \mathrm{N}$ yang tinggi (kandungan unsur $\mathrm{N}$ yang relatif rendah) akan menyebabkan proses degradasi berlangsung lebih lambat karena nitrogen akan menjadi faktor penghambat (growth-rate limiting factor). Rasio $\mathrm{C} / \mathrm{N}$ tergantung dari kontaminan yang ingin didegradasi, bakteri serta jenis nitrogen yang digunakan. Beberapa penelitian menunjukkan bahwa rasio $\mathrm{C} / \mathrm{N} / \mathrm{P}$ optimum pada proses biodegradasi adalah 100:10:1 (Wulan dkk., tt).

Bakteri menggunakan komponen residu jerami padi sebagai substrat untuk memperoleh energi yang dibentuk melalui oksidasi senyawa organik, dengan produk utama $\mathrm{CO}_{2}$ yang dilepas kembali ke alam, dan sumber karbon untuk sintesis sel baru. Dekomposisi ini disebut juga sebagai respirasi mikroba atau mineralisasi, yang merupakan salah satu bagian dari siklus karbon.

Berdasarkan

penelitian,

diperoleh bahwa penggunaan briket isolat bakteri pendegradasi solar dengan ukuran berbeda mempengaruhi kemampuan bakteri dalam menghasilkan Asam n-Oktanoat. Konsentrasi Asam n-Oktanoat yang dihasilkan dari briket bakteri pendegradasi solar dengan komposisi jerami padi $4 \%$ ditambahkan urea $1 / 4$ dari berat jerami padi $4 \%$ dalam media cair sebagai hasil dari biodegradasi solar. Data konsentrasi Asam nOktanoat yang didapatkan dari pelaksanaan titrasi pada 45 sampel uji, pada saat melaksanakan titrasi dilakukan pengulangan pada setiap sampel sebanyak 3 kali untuk mendapatkan rata-rata volume yang tepat saat terjadi kemunculan pertama perubahan warna pada sampel, yakni berwarna hijau tua hingga terjadi perubahan munculnya warna kemerahan pada sampel, dengan mengambil $5 \mathrm{ml}$ pada setiap sampel yang diulangi sebanyak 3 kali. Setelah didapatkan rata-rata volume yang tepat pada masing-masing sampel kemudian dikalkulasi dengan memasukkan rumus kimia untuk menentukan konsetrasi Asam n-Oktanoat pada setiap sampel Sehingga didapatkan data konsentrasi Asam n-Oktanoat seperti diatas. Perbedaan konsentrasi dari tiga ukuran briket bakteri tersebut dapat dilihat pada grafik dibawah ini. 


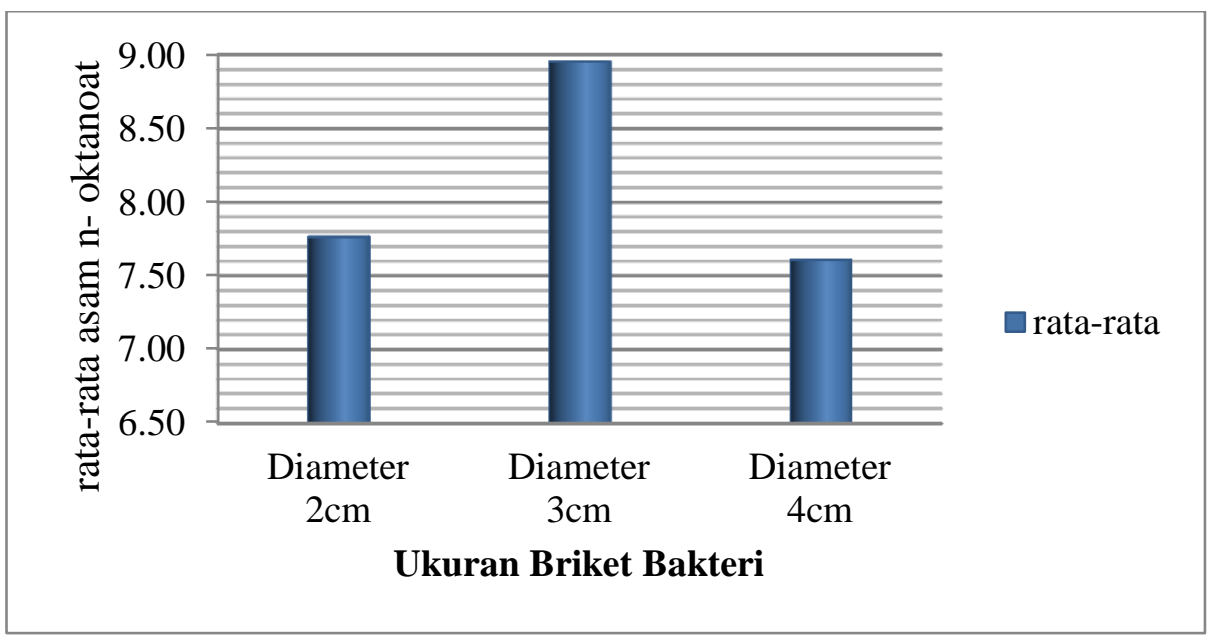

Gambar 4 Diagram batang jumlah konsentrasi Asam n-Oktanoat yang dihasilkan oleh Briket Bakteri Pendegradasi Solar

Berdasarkan gambar 4 terlihat bahwa ukuran briket isolat bakteri pendegradasi solar berpengaruh terhadap asam oktanoat yang dihasilkan oleh bakteri yang sudah dibiakkan di dalam briket jerami padi. Pada ukuran briket isolat bakteri ukuran diameter $3 \mathrm{~cm}$ yang dimasukkan dalam media cair yang menghasilkan konsentrasi Asam nOktanoat yang paling optimal.Asam nOktanoat digunakan sebagai parameter kemampuan bakteri dalam mendegradasi solar, semakin banyak Asam n-Oktanoat yang dihasilkan, maka semakin baik pertumbuhan bakteri dalam ukuran jerami yang dimaksukkan dalam media cair.

Didapatkan bahwa ukuran briket isolat bakteri pendegradasi solar yang terbuat dari jerami padi dan tambahan urea dapat memberikan pengaruh terhadap Asam n-Oktanoat yang dihasilkan oleh bakteri pada proses biodegradasi minyak solar. Hal tersebut dapat dilihat dari rata-rata konsentrasi Asam n-Oktanoat pada ukuran $2 \mathrm{~cm}$ rata-rata Asam n-Oktanoat yang dihasikan adalah 7,76, pada ukuran 3 $\mathrm{cm}$ rata-rata konsentrasi Asam nOktanoat yang dihasilkan adalah 8,95. Sementara pada ukuran $4 \mathrm{~cm}$ rata-rata konsentrasi Asam n-Oktanoat yang dihasilkan adalah 7,61.

Konsentrasi Asam n-Oktanoat paling optimal pada ukuran bakteri pendegradasi solar $3 \mathrm{cml}$. Ukuran briket bakteri pendegradasi solar $3 \mathrm{~cm}$ tersebut memiliki komposisi campuran bahan dan suplemen paling baik, sehingga pada saat membiakan bakteri di dalam briket, sumber karbon lebih banyak. Konsentrasi asam n-oktanoat merupakan hasil dari biodegradasi minyak solar oleh bakteri pendegradasi minyak solar dengan bantuan senyawa biosurfaktan yang berfungsi untuk mengubah minyak solar menjadi butiran-butiran kecil yang disebut misel sehingga lebih mudah diuraikan oleh bakteri, Proses biodegrdasi minyak solar tersebut menyebabkan terlepasnya ion $\mathrm{H}^{+}$dari ikatan hidrokarbon ke lingkungan, sehingga keasaman lingkungan meningkat. Hal tersebut 
yang menyebabkan $\mathrm{pH}$ media yang awalnya netral, kemudian menjadi asam dan semakin hari akan bertambah asam.

\section{SIMPULAN DAN SARAN \\ Simpulan}

Komposisi $4 \%$ adalah komposisi jerami padi yang tepat bagi pertumbuhan optimum bakteri pendegradasi solar. Ukuran yang paling optimal dipergunakan adalah briket bakteri pendegradasi solar yang memiliki diameter $3 \mathrm{~cm}$ yaitu dengan rata-rata konsentrasi Asam n-Oktanoat yang dihasilkan adalah 8. Genus bakteri pendegradasi solar yang pertumbuhannya paling optimum pada komposisi jerami padi yang tepat tersebut adalah genus Pseudomonas. Isolat bakteri pendegradasi minyak solar mampu mendegradasi secara soliter atau dalam bentuk konsorsium tetapi dalam bentuk konsorsium pertumbuhan lebih optimum.

\section{Saran}

Penelitian ini menggunakan jerami padi sebagai bulking agent terhadap kerja bakteri pendegradasi solar dalam mendegradasi solar. Bagi yang berminat meneliti hal yang sama, jerami padi bisa diganti dengan alternatif substrat yang lain. Pada penelitian ini rasio C/N/P hanya ditentukan secara tidak langsung dari jumlah total koloni bakteri yang tumbuh, sehingga tidak ada keakuratan data secara kuantitatif karena keterbatasan sarana dan prasarana.

\section{UCAPAN TERIMAKASIH}

Tim peneliti mengucapkan terimakasih atas kesempatan yang telah diberikan oleh Lembaga Penelitian Undiksha dengan pembiayaan dari Daftar Isian

\begin{tabular}{llrr} 
Pelaksanaan & \multicolumn{2}{c}{ Anggaran } & (DIPA) \\
Universitas & Pendidikan & Ganesha \\
dengan & SPK & Nomor & Nomor \\
5/UN48.14/PL/2013 & Tanggal 1 April \\
2013. & & &
\end{tabular}

\section{DAFTAR PUSTAKA}

Atlas, R. M. \& Bartha, R. 1987. Microbial Ecology: Fundamental and Applications. California : Benjamin/Cummings Sciences Publishing.

Brock, T. D., Madigan, M. T. \& Martinko, J. 2003. Biology of Microorganisms. New York : Prentice Hall.

Gaur, A. C. 1982. A Manual of Rural Composting: In Improving Soil Fertility Through Organic Recycling. Project Field Document No. 15. Food and Agricultural Organization of The United Nation: Rome.

Gunam, I B W, Buda, K. \& Guna, I M Y. S. 2010. Pengaruh Perlakuan Delignifikasi Dengan Larutan $\mathrm{NaOH}$ dan Konsentrasi Substrat Jerami Padi Terhadap Produksi Enzim Selulase dari Aspergillus Niger NRRL A-II, 264. Jurnal Biologi. (Online), XIV(1), 2010: 55-61, (http://ojs.unud.ac.id, diakses tanggal 24 Juli 2013).

Makarim, A. K., Sumarno, Suyamto. 2007. Jerami Padi: Pengelolaan dan Pemanfaatan. Bogor: Pusat Penelitian dan Pengembangan Tanaman Pangan.

Mulyadiharja, S., Ristiati, N. P. \& Setiabudi, I. 2010. Isolasi, Identifikasi dan Uji Kemampuan 
Degradasi Mikroba Pengurai Minyak Bumi dari Perairan Pelabuhan Celukan Bawang, Buleleng. Jurnal Penelitian dan Pengembangan Sains \& Humaniora. (Online), 4(1), April 2010: 15-27,

(http://www.digilib.ui.ac.id, diakses tanggal 24 Desember 2012).

Nugroho, A. 2006. Biodegradasi Sludge Minyak Bumi dalam Skala Mikrokosmos: Simulasi Sederhana Sebagai Kajian Awal Bioremediasi Land Treatment. Makara, Teknologi. (Online), 10(2), November 2006: 82-89 (http://www.repository.ui.ac.id ,diakses tanggal 20 Desember 2012).

Nurhariyati, T., Ni'matuzahroh \& Surtiningsih, T. 2006. Biodegradasi Minyak Oleh Rhodotorula dan Candida Hasil Isolasi dari Pelabuhan Tanjung Perak Surabaya. Jurnal Discoveri Indonesia. (Online), 12(1), Desember 2006, USA (http://www.scribd.com, diakses tanggal 20 Desember 2012).

Obayuri. 2006. Biodegrability of Surfactant. (Online), (http://www.technologysurfactant.html, diakses tanggal 23 Desember 2012).

Reisfeld, A., Rosenberg, E. \& Gutnick, D. 1972. Microbial Degradation of Crude Oil: Factors Affecting The Dispersion in Sea Water by Mixed and Pure Cultures. Applied Microbiology. (Online), 24(3), September 1972: 363368, (http://www.tau.ac.il, diakses tanggal 01 Januari 2013).

Ristiati, N P. 2000. Pengantar Mikrobiologi Umum. Jakarta: Direktorat Jenderal Pendidikan Tinggi, Departemen Pendidikan Nasional.

Zobel, C. 1973. Action of Microorganism on Hydrocarbons, (Online) (http://www.mmbr.asm.org, diakses tanggal 14 Februari 2013). 